\title{
Use of Kaolin For Protection Against Flavobacteriosis In Oreochromis niloticus (b)
}

Eissa I.A.M., Derwa H.I., Mona M. Ismail, Maather M.M El-Lamie and Elsayed T.M.*

Dept. of Fish Diseases and Management, Faculty of Vet. Medicine, Suez Canal University.

*Fish Farming unit, Faculty of Vet. Medicine, Suez Canal University

\begin{abstract}
Because of the difficulties facing the treatment of flavobacteriosis, this study aimed to evaluate kaolin (a type of clay) for the prevention of such disease in Oreochromis niloticus. Addition of kaolin at rate of $1 \mathrm{~g} / \mathrm{L}$, to the water aquaria, $5 \mathrm{~min}$ prior the challenge of $O$. niloticus, protected the fish against columnaris disease $(100 \%)$ and improved survival $(93.7 \%)$ as compared to untreated fish (50 and $66.7 \%$, respectively). The re-isolated strain from untreated challenged fish confirmed through a pair of 16S RNA gene-based PCR primers specific for F.columnare and produced unique and clear PCR bands of the expected size (675 base pair).
\end{abstract}

Key words: Kaolin, protection, $F$. columnare, flavobacteriois, O. niloticus

\section{Introduction}

Columnaris disease can infect fish at any age, under a variety of water conditions, and during any season of the year (Griffin, 1992). In USA, columnaris disease considered the second most prevalent bacterial disease causing economic losses secondary to Enteric septicemia of catfish (USDA, 2003). In addition, Eissa (1993 and 1994) recorded that Falvobacterium colamnare is the primary cause of mass mortalities in cultured Oreochromis niloticus and Mugil cephalus, respectively in Egypt.

Despite its importance, columnaris disease still faces some of the difficulties regarding the diagnosis and chemotherapy. Recently, the use of antibiotic as growth promotors in animal diets has been eliminated or limited in many countries because of concern related to cross-resistance to antimicrobial agents that are used in human medicine (Barton, 2000; Anonymous, 2002; Castro, 2005 and Chen et al., 2005). This limitation prompted the search and development of alternatives such as organic acids, enzymes, probiotics, plant extract and essential oils. Of these alternatives, Kaolin, a feed additive in animal nutrition affects growth performance, has been investigated formerly and recently (Savory, 1984; Sakata, 1986 and Owen et al., 2012). The use of Dietary Kaolin improves the 
nutrient digestibility and enzymatic activity of gastrointestinal secretion (Ouhida et al, 2000 and Alzueta et al, 2002).

Kaolin, a natural aluminum silicate hydrate $(\mathrm{Al} 2(\mathrm{OH}) 4 \mathrm{SiO} 5), \quad$ is authorized for use as a food additive. In addition, according to last revision of Code of Federal Regulations (2014), issued by USFDA, kaolin is permitted as generally recognized as safe (GRAS) used as an indirect human food ingredient with no limitation. Additional benefits related to the use of kaolin are that there is no risk of antibiotic resistance and no harmful chemical residues are introduced into the environment or the eventual consumer product.

Due to its adsorption character and it has no toxicity (Anonymous, 1998), using of kaolin is recommended to overcome the adverse effects produced by toxic agents such as aflatoxins (AbdelWahhab et al, 1999; Phillips, 1999), metabolites of plant (alkaloids, tannins), heavy metals pathogenic microorganisms, (Hassen et al, 2003; Katsumata et $a l, 2003)$, enterotoxins caused by diarrhea (Dominy et al, 2004). Besides, Using of kaolin in aquaculture as bulking agents in pelleted feeds (Grove et al, 1978 and Jobling, 1981) and to reduce egg adhesion in hatchery operations (Mizuno et al, 2004) have been demonstrated.

Recently, Beck et al (2015) demonstrated survival improvement, reduction of gill infection by using kaolin and reduction of bacterial attachment to target tissues of columnaris disease in channel catfish by binding ability to $F$. columnare .

This study was carried out to evaluate the role of kaolin in prevention of columnaris disease in Oreochromis niloticus experimentally infected with Flavobacterium columnare.

\section{Materials and methods}

\section{1) Fish:}

A total of 120 alive and apparently healthy O.niloticus with an average body weight $50 \pm 5 \mathrm{~g}$ were collected from a fish farm from Ismailia governorate. They were transported to Fish Diseases and Mangement Depatment of Suez Canal University. Fish were fed on standard commercial ration containing $25 \%$ crude protein. The diet was daily provided as $3 \%$ of body weight.

\section{2) Aquaria}

Fish were kept in glass aquaria

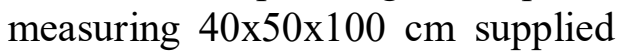
with decolorinated tap water and air pumps for continuous aeration and filter for continuous filtration.

\section{3) Kaolin:}

Kaolin (A12 Si205(OH) 4) was obtained from (Duggan veterinary company, Ireland) in form of $1 \mathrm{Kg}$ white powder package.

4) Flavobacterium columnare

\section{strain:}


A well identified Flavobacterium columnare strain was kindly obtained from Dept. of Fish Diseases and Management, Faculty of Vet. Medicine, Suez Canal University.

\section{Challenge experiment:}

One hundred and twenty apparently healthy O.niloticus were equally divided into 4 groups (30 fish for each group). The flow-through system provided with water at a flow rate of approximately $1 \mathrm{~L} / \mathrm{min}$ and the temperature was maintained at $26 \pm 0.5$ C. According to Mitchell and Farmer (2010), fish were acclimiated to the experimental conditions for 10 days. The four aquaria were randomly assigned to one of four treatment groups: group one remained not treated with kaolin and challenged by cutaneous scrubbing and waterborne exposure to $F$. columnare (positive control); group two was treated with kaolin then challenged; group three was kaolin-treated non-challenged group and group four remained nontreated non-challenged (negative control).

Kaolin was added slowly to water at a rate of $1 \mathrm{~g} / \mathrm{L}$, near air pumping, to facilitate mixing and 5 minutes prior to challenge, to give enough mixing time and to initiate the ultralow flow (Beck et al, 2015).

Fish were challenged by adding 5 $\mathrm{ml}$ of the bacterial suspension $(4 \mathrm{x}$
$10^{7}$ ) from the virulent identified strain to each $10-\mathrm{L}$ water.

\section{Molecular characterization:}

\section{Bacterial isolates:}

For re-isolation of bacteria from challenged-diseased fish, a sterile swab was rasped in the characteristic lesions of the fish. The material was then immediately transferred to Ordals agar and incubated at $22^{\circ} \mathrm{C}$ for $72 \mathrm{hrs}$. The bacterial isolate was identified using PCR .

\section{Results}

Kaolin protection against flavobacteriosis:

Addition of kaolin at rate of $1 \mathrm{~g} / \mathrm{L}$, to the water aquaria containing $O$. niloticus, 5 min prior the challenge protected fish against columnaris disease as it prevented the appearance of lesions (100\%) as compared to untreated fish $(0 \%)$ (table 1).

Molecular Identification of Flavobacterium columnare by polymerase chain reaction (PCR). A pair of 16S RNA gene-based PCR primers, were used for detection of F.columnare re-isolates from challenged fish. The reisolated strain from diseased fish challenged and untreated (group 1) produced unique and clear PCR bands of the expected size (675 base pair) (Fig. 1 ) PCR confirmed that the re-isolated strain was F.columnare. 
Table (1) Effect of kaolin on diseased O. niloticus with flavobacteriosis

\begin{tabular}{|c|c|c|c|c|c|c|c|}
\hline \multirow{2}{*}{ Group } & \multirow{2}{*}{$\begin{array}{c}\text { No. } \\
\text { of }\end{array}$} & \multirow{2}{*}{$\begin{array}{c}\text { Kaolin } \\
\text { freatment }\end{array}$} & \multirow{2}{*}{$\begin{array}{c}\text { Challenge with } \\
\text { F.columnare }\end{array}$} & \multicolumn{2}{|c|}{ Dead fish } & \multicolumn{2}{|c|}{$\begin{array}{c}\text { Diseased } \\
\text { fish }\end{array}$} \\
\cline { 5 - 8 } & & & No. & \% & No. & \% \\
\hline 1 & 30 & Non & Challenged & 10 & 33.3 & 20 & 66.67 \\
\hline 2 & 30 & Treated & Challenged & 2 & 6.7 & 0 & 0 \\
\hline 3 & 30 & Treated & Non & 0 & 0 & 0 & 0 \\
\hline 4 & 30 & Non & Non & 0 & 0 & 0 & 0 \\
\hline
\end{tabular}

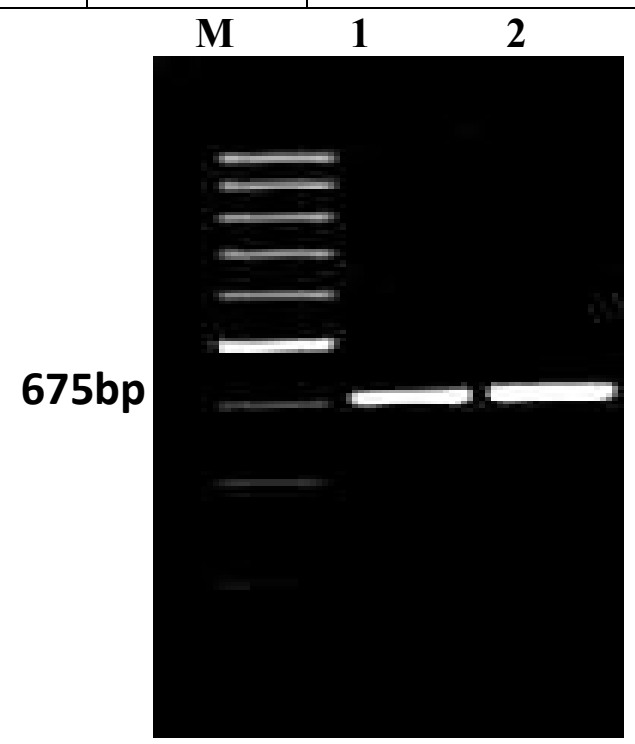

Fig. (1): Agarose gel electrophoresis of PCR for re-isolated strain.

M: marker- Lane $1=$ control positive (strain of challenge).

Lane $2=$ reisolated strain from diseased fish.

\section{Discussion}

Since 2005, the European Commission implemented an absolute ban on the use of antibiotic growth promoters in animal diets (Castro, 2005; Chen et al, 2005), mainly due to the potential occurrence of cross-resistance to antimicrobial agents that are used in human medicine.

Kaolin represents one of the alternatives that is permitted as food additives in the European Union and approved as GRAS indirect food materials in United State (CFR, 2014) without risk of antibiotic resistance or harmful chemical residues addition to the environment or the eventual consumer product.

Our results revealed that addition of kaolin prior to the challenge of $O$. niloticus protected the fish against columnaris disease as the mortality reduced to $6.7 \%$ in kaolintrreated challenged group while 
reached to $33.3 \%$ in untreated challenged group. This finding is in complete accordance with that reported recently by Beck et al (2015) who reported the reduction of gill infection by using kaolin and reduction of bacterial attachment to target tissues of columnaris disease in channel catfish lead to survival improvement of infected fish. They demonstrated that Kaolin adsorbs the bacterium and binds to it, thereby preventing it from attaching to the fish and causing the disease. Flavobacterium species have a highly susceptiblity to be adsorped by kaolin (Esterman and McLaren, 1959 and Soda et al, 1999). Adsorption phenomenon means an accumulation of a number of molecules, ions, or atoms that occur at the boundaries of the two phases. The amount of adsorbate accumulates on the adsorbent is affected by particle size and surface area of the adsorbent and the adsorbate. Condensed molecule is called adsorbate, while the substrate surface (solid or liquid) is called adsorbent (Prawira, 2008).

Because of its adsorbent capability, kaolin was added to reduce egg adhesion in hatchery operations in aquaculture (Mizuno et al, 2004) and added to animal diets to prevent enteric diseases through its ability to absorb enterotoxins and significant mycotoxins (AbdelWahhab et al, 1999; Phillips, 1999; Boranic, 2000; Dominy et al, 2004 and Trckova et al, 2004).
Regarding the molecular identification of the re-isolated strain from lesions appeared on the challenged groups, by using PCR , the results confirmed without doubt that, it was $F$. columnare. This is in agreement with Mohamed and Refat (2011) who confirmed molecularly all of the positive isolated of $F$. columnare which isolated from Nile tilpia by means of PCR

The results concluded that Kaolin not only offers producers an alternative to antibiotics in combating columnaris disease, but it also provides an inexpensive treatment for a costly fish disease because plentiful clay is available in Egypt.

\section{References:}

Abdel-Wahhab, M.A.; Nada, S.A. and Amra, H.A. (1999): Effect of aluminosilicates and bentonite on aflatoxininduceddevelopmental toxicity in rat. Journal of Applied Toxicology, 19, 199-204.

Alzueta C.; Ortiz L.T.; Rebole A.; Rodriguez M.L; Centreno C. and Trevino J. (2002): Effects of remoral of mucilage and enzyme of sepiolite supplement on the nutrient digestibility and metabolizable energy of a diet containing linseed in broiler chickens. Animal Feed Science Technology, 97: 169-181.

Anonymous (1998): Kaolin clay Tolerance Requirement Exemption 2/98. Environmental Protection Agency (EPA), Federal Register 
February 25, 1998, 63 (37), 94279430.

Anonymous (2002): European Union Information CenterDelegation of the European Commission to the Czech Republic. http://www.smocr.cz/old_smocr/

Barton, M.D. (2000): Antibiotic use in animal feed andits impact on human health. Nutrition Research Reviews, 13, 279-299.

Beck, B. H.; Barnett, L. M.; Farmer, B. D.; Peatman, E. and Carter, D. (2015): Kaolinitic clay protects against Flavobacterium

columnare infection in channel catfish Ictalurus

punctatus (Rafinesque). Journal of Fish Diseases Volume 38, Issue 3, pages 241-248.

Boranic, M. (2000): What a physician should know about zeolites (in Croatian). LijecnickyVjesnik, 122, 292-298.

Castro, M. (2005): Use of additives on the feeding of monogastricanimals. Cuban Journal of Agricultural Science, 39, 439445.

Chen, Y.J.; Kwon, O.S.; Min, B.J.; Son, K.S.; Cho, J.H.; Hong, J.W.; Kim, I.H. (2005): The effects of dietary Biotite V supplementation as an alternative substance to antibiotics in growing pigs. Asian-Australasian Journal of Animal Sciences, 18, 1642-1645.

Code of Federal Regulations (CFR) (2014): Title 21: PART 186 -- INDIRECT FOOD SUBSTANCES AFFIRMED AS
GENERALLY RECOGNIZED AS SAFE; Subpart B--Listing of Specific Substances Affirmed as GRAS; Vol. 3, sec. 186.1256 clay (kaolin).

Dominy, N.J.; Davoust, E. and Minekus M. (2004): Adaptive function of soil consumption: an in vitro study modelling the human stomach and small intestine. The Journal of Experimental Biology, 207, 319-324.

Eissa I.A.M (1993): Role of Procellain crabs as enemies of marine cultured mullet in Lake Temsah. Zag. Vet. J.21(5):926-935.

Eissa I.A.M (1994): Studies on sloughing tail among cultured tilapia. $6^{\text {th }}$ Sci. Cong., Fac. Vet. Med., Assiut, Egypt.

Esterman E.F. \& McLaren A.D. (1959): Stimulation of bacterial proteolysis by adsorbents. Journal of Soil Science 10, 64-78.

Griffin B.R.(1992): A simple procedure for adentification of Cytophaga columnaris Journal of Aquatic Animal Health 4 :63-66.

Grove, D.J.; Loizides, L.G. and Nott, J. (1978): Satiation amount,frequency of feeding and gastric emptying rate in Salmo gairdneri Journal of Fish Biology12, 507-516.

Hassen, A.; Jamoussi, F.; Saidi, N.; Mabrouki, Z. and Fakhfakh, E. (2003): Microbial and cooper adsorption by smectiticclay - an experimental study. Environmental Technology, 24, 1117-1127.

Jobling, M. (1981): Dietary digestibility and the influence of 
food components on gastric evacuation in plaice, Pleuronectes platessa L. Journal of Fish Biology19,29-36

Katsumata, H.; Kaneco, S.; Inomata, K.; Itoh, K.; Funasaka, K.; Masuyama, K.; Suzuki, T. and Ohta, K. (2003): Removal of heavy metals in rinsing wastewater from plating factory by adsorption with economical viable materials. Journal of Environmental Management, 69, 187-191.

Mitchell, A.J. and Farmer, B.D.(2010): Evaluation of an ultra low-flow water delivery system for small experimental tanks.North American Journal of Aquaculture72 , 195-200

Mizuno, S.; Sasaki Y.; Omoto, N. and Imada, K. (2004): Elimination of adhesiveness in the eggs of shishamo (smelt Spirinchus) lanceolatus using kaolin treatment to achieve high hatching rate in an environment with a high iron concentration Aquaculture242, 713-726.

Mohamed, H.M.and Refat, N.A.(2011): Pathological Evaluation of probiotic, Bacillus subtilis, against $F$. columnare in Tilapia Nilotica (Oreochromis Niloticus) Fish in Sharkia Governorate, Egypt. Journal of American Scince 7: 244256.

Ouhida, I.J.; Perez, J.F.; Piedrafita, J.and Gasa, J. (2000): The effects of sepiolite in the broiler chicken diets of high, medium and low viscosity, productive performance and nutritive value. Animal Feed Science Technology, 85:183-194.

Owen, O.J.; Nodu, M.B.; Dike, U.A. and Ideozu, H.M. (2012): The Effects of Dietary Kaolin (Clay) as Feed Additive on the Growth Performance of Broiler Chickens. Greener Journal of Agricultural Sciences; Vol. 2 (6), pp. 233-236.

Phillips, T.D. (1999): Dietary clay in the chemoprevention of aflatoxin-induced disease. Toxicological Sciences, 52, 118126.

Prawira (2008): Biosorpsion of Heavy Metals. Reseach Journal Of Chemistry And Environment. p. 7178.

Sakata, T. (1986): Effects of unpalatable dietary bulk and short chain fatty acids on the tissue weight and epithelial cell proliferation rate of the digestive tract in rats. J. Nutr. Sci. Vitaminol. (Tokyo), 32, 355-362.

Savory, C. J. (1984): Regulation of food intake by brown Leghorn cockerels in response to dietary dilution with kaolin. Brit. Poult. Sci., 25, 253-258.

Soda, S.; Ike M. and Fujita, M. (1999): Adsorption of bacterial cells onto activated sludge flocs. Journal of Bioscience and Bioengineering87, 513-518.

Trckova, M.; Matlova, L.; Dvorska, L. and Pavlik, I. (2004): Kaolin, bentonite, and zeolites as feed supplements for animals: health advantages and risks. Veterinarni Medicina, 49, 389-399. 
United States Department of production practices. Center for Agriculture (2003): Reference of Epidemiology and Health, Fort 2002 U. S. catfish health and Collins, Colorado. P. 64-67.

\section{استخدام الكاولين للحماية من الفلافوبكتريوسز (ب)}

أسماعيل عبد المنعم محمد عيسى، حسن ابراهيم محم دروه، منى محمود اسماعيل، مآثر محمد منير

$$
\text { اللمعي وث*تيسير السيد }
$$

قسم أمراض و رعاية الأسماك-كلية الطب البيطرى-جامعة قناة السويسيس السبل

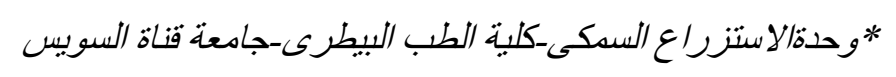

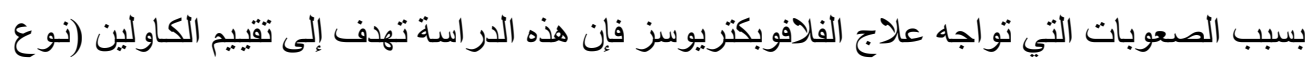

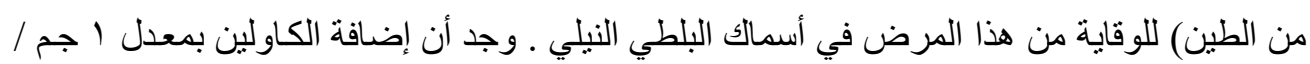

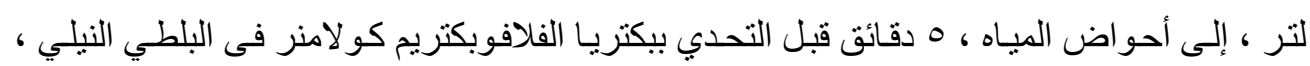

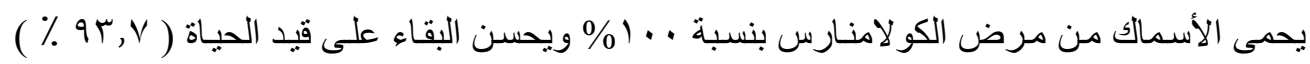

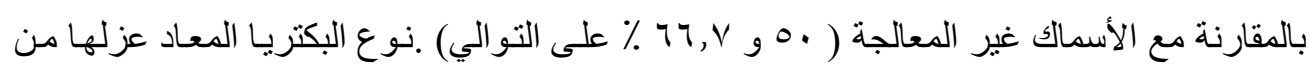

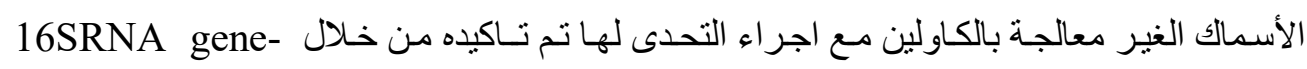
based PCR اضحة من الحجم المنوقع ( base-pair TVO ) . ال 